\title{
Hypercoagulopathy in Severe COVID-19: Implications for Acute Care
}

\author{
Alicia A. C. Waite ${ }^{1,2}$ David O. Hamilton ${ }^{2}$ Roberto Pizzi ${ }^{3}$ Walter Ageno ${ }^{3}$ Ingeborg D. Welters ${ }^{1,2}$ \\ ${ }^{1}$ Institute for Life Course and Medical Sciences, University of \\ Liverpool, Liverpool, United Kingdom \\ 2 Department of Intensive Care Medicine, Royal Liverpool University \\ Hospital, Liverpool University Hospitals NHS Foundation Trust, \\ Liverpool, United Kingdom \\ ${ }^{3}$ Department of Medicine and Surgery, University of Insubria, \\ Varese, Italy \\ Thromb Haemost 2020;120:1654-1667. \\ Address for correspondence Ingeborg D. Welters, MD, PhD, MA, \\ Institute for Life Course and Medical Sciences, University of Liverpool, \\ Liverpool L69 3BX, United Kingdom \\ (e-mail: I.Welters@liverpool.ac.uk).
}

\begin{abstract}
Keywords

- anti-coagulation

- coagulopathy

- immunothrombosis

- severe acute respiratory syndrome

- venous thrombosis

COVID-19 was first described in late 2019 and has since developed into a pandemic affecting more than 21 million people worldwide. Of particular relevance for acute care is the occurrence of COVID-19-associated coagulopathy (CAC), which is characterised by hypercoagulability, immunothrombosis and venous thromboembolism, and contributes to hypoxia in a significant proportion of patients. This review describes diagnosis and treatment of CAC in the emergency department and in intensive care. We summarise the pathological mechanisms and common complications of CAC such as pulmonary thrombosis and venous thromboembolic events and discuss current strategies for thromboprophylaxis and therapeutic anti-coagulation in the acute care setting.
\end{abstract}

\section{Introduction}

In late 2019, severe acute respiratory syndrome coronavirus 2 (SARS-CoV-2) was identified as the cause of the global coronavirus disease 2019 (COVID-19) pandemic. ${ }^{1,2}$ In patients with COVID-19, higher than expected rates of venous and arterial thrombosis have been reported. ${ }^{3-7}$ As a consequence, the prognostic role of biochemical markers of coagulopathy, the need for adequate clinical suspicion of the presence of venous thromboembolism (VTE) and the role and optimal doses of anti-coagulant drugs have become a matter of intense discussion and of particular relevance in the emergency department (ED) and in intensive care units (ICUs).

Since the first reports of overt disseminated intravascular coagulation (DIC) in non-survivors of COVID- $19,{ }^{8}$ it has become clear that the biochemical coagulation phenotype of patients with COVID-19 differs to that observed in patients with sepsis-induced coagulopathy (SIC) ${ }^{8-10}$ Therefore, the

received

August 16, 2020

accepted after revision

November 9, 2020

term COVID-19-associated coagulopathy (CAC) has been coined to describe the unique changes in haemostasis and fibrinolysis observed in SARS-CoV-2 infection. ${ }^{11}$ CAC has been characterised clinically, ${ }^{3,12}$ radiologically, ${ }^{4-6}$ and on autopsy. ${ }^{13-17}$ Coagulopathy is, however, clearly not unique to COVID-19 and micro- and macrovascular thrombi are common in critically ill patients. ${ }^{18}$

\section{Prevalence of VTE in Patients with COVID-19}

A striking feature of COVID-19 is the high incidence of pulmonary and extrapulmonary thrombosis observed in patients with severe disease (-Table 1). Depending on investigations performed, follow-up time documented and thromboprophylactic regimens used, the reported incidence of VTE varies between 6 and $86 \%$, with most trials reporting prevalences between 15 and $40 \%$. This is significantly higher than described for non-COVID-related critical illness where there is a VTE prevalence between 5 and $30 \%{ }^{3,4,19-26}$ The

(c) 2020. Thieme. All rights reserved. Georg Thieme Verlag KG,

Rüdigerstraße 14,

70469 Stuttgart, Germany
DOI https://doi.org/ 10.1055/s-0040-1721487. ISSN 0340-6245. 


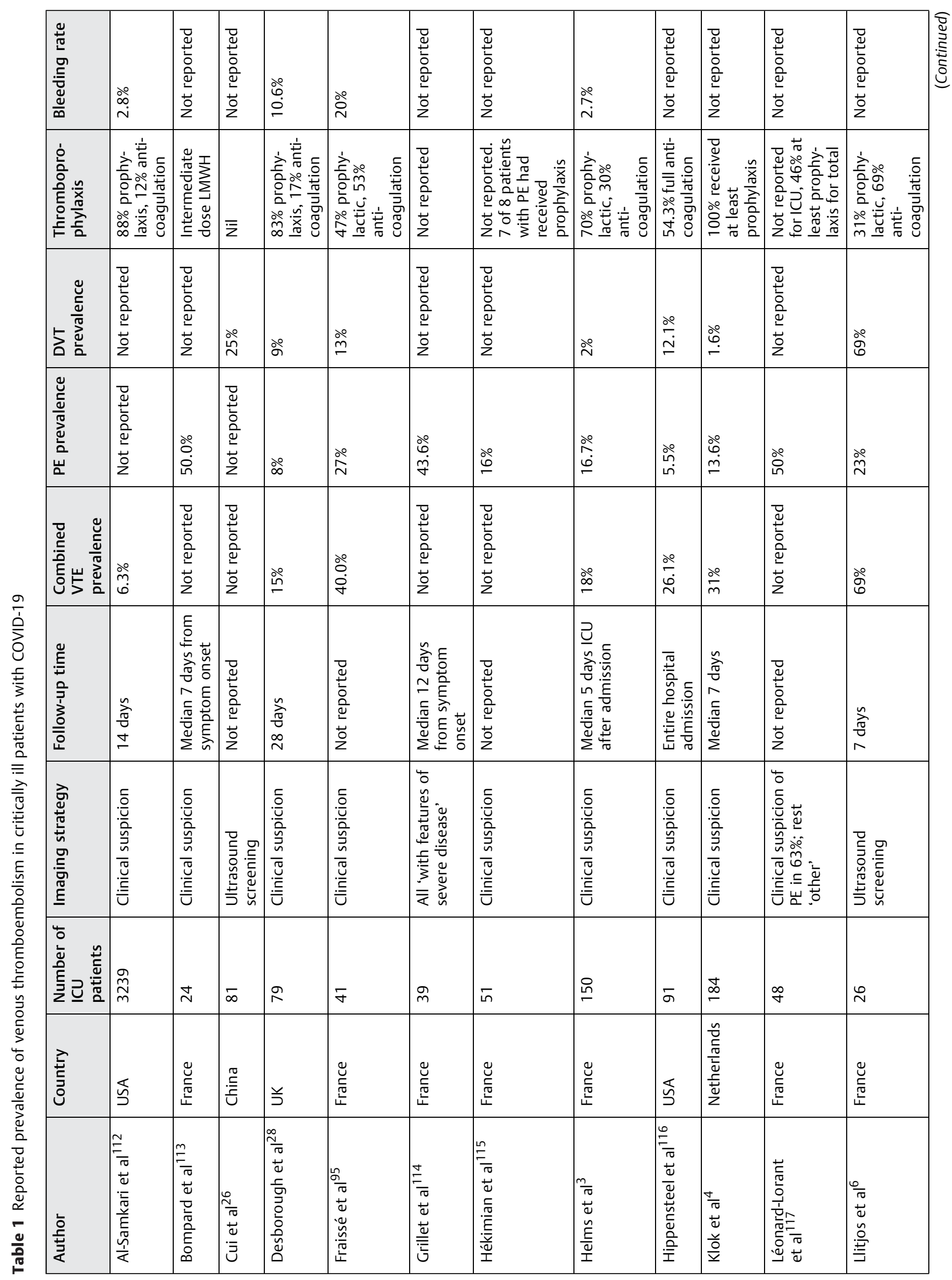




\begin{tabular}{|c|c|c|c|c|c|c|c|c|c|c|c|c|}
\hline 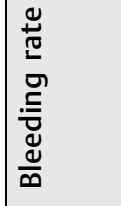 & ○̊ & 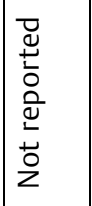 & 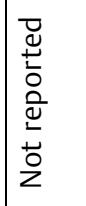 & 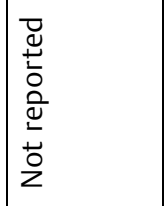 & 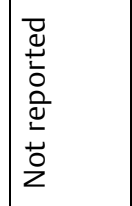 & 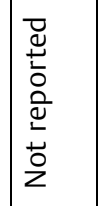 & 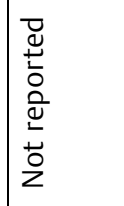 & 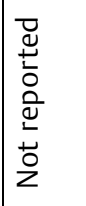 & 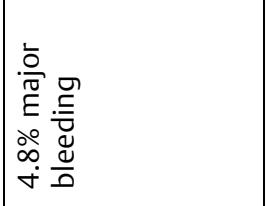 & 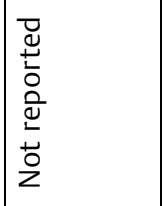 & 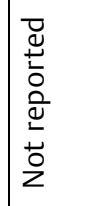 & 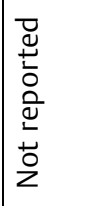 \\
\hline 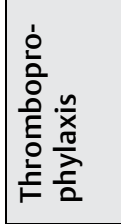 & 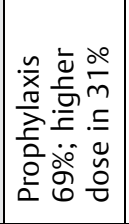 & 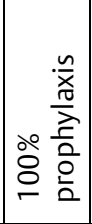 & 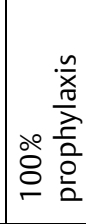 & 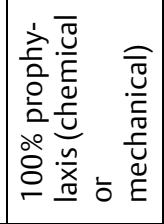 & 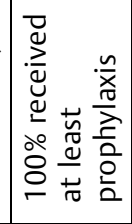 & 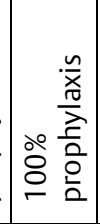 & 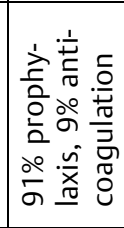 & 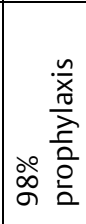 & 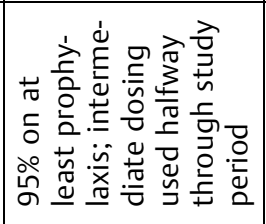 & 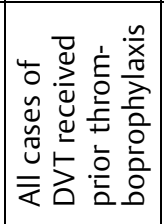 & 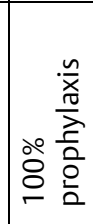 & 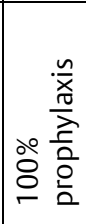 \\
\hline 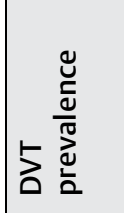 & $\underset{\stackrel{+}{\sim}}{\stackrel{\circ}{+}}$ & $\stackrel{\circ}{\stackrel{ }{~}}$ & $\begin{array}{l}\stackrel{\circ}{\leftrightarrow} \\
\stackrel{\sim}{\sim}\end{array}$ & 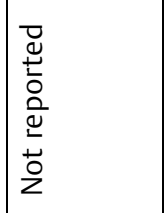 & ळे & 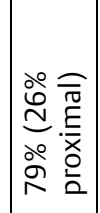 & ஓ̊ํํ & 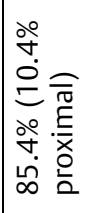 & 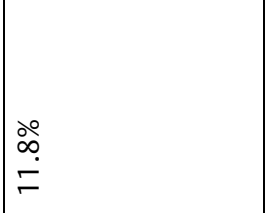 & $\stackrel{\circ}{\stackrel{े}{~}}$ & ○̊ & 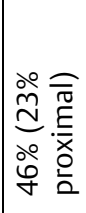 \\
\hline 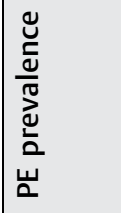 & $\begin{array}{l}\stackrel{े}{~} \\
\stackrel{+}{*}\end{array}$ & ஓें & $\begin{array}{l}\text { லे } \\
\dot{\sigma}\end{array}$ & 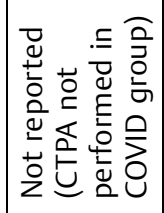 & 운 & 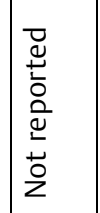 & $\begin{array}{l}\text { ல̊ } \\
\text { iे }\end{array}$ & 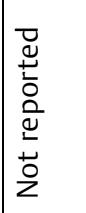 & $\begin{array}{l}\stackrel{\circ}{ஸ ்} \\
\stackrel{\sim}{N}\end{array}$ & 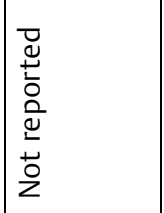 & ڤั & 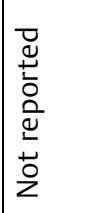 \\
\hline 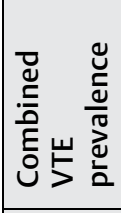 & 产 & 犬े & $\stackrel{\circ}{\stackrel{\circ}{~}}$ & 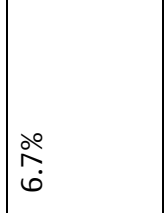 & $\stackrel{\stackrel{\circ}{\sim}}{\stackrel{f}{~}}$ & 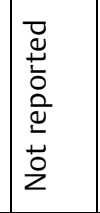 & 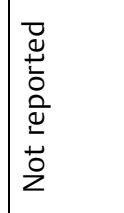 & $\begin{array}{l}\stackrel{\circ}{\dagger} \\
\text { ஸे }\end{array}$ & $\begin{array}{l}\stackrel{\circ}{m} \\
\stackrel{m}{\sim}\end{array}$ & 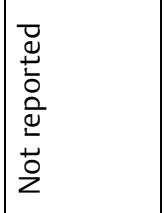 & ঐे & 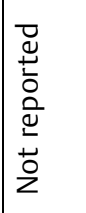 \\
\hline 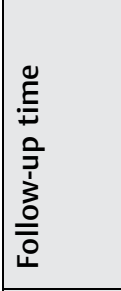 & 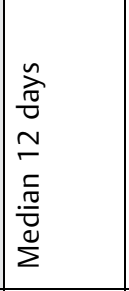 & $\begin{array}{l}\stackrel{n}{\vec{\pi}} \\
\frac{0}{0} \\
0 \\
-\end{array}$ & 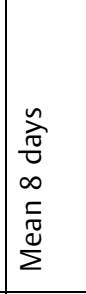 & 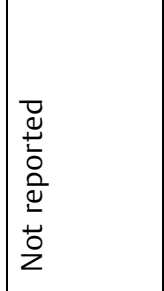 & 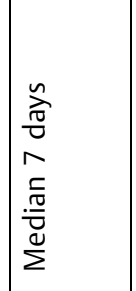 & 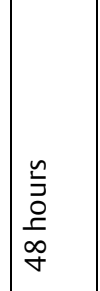 & 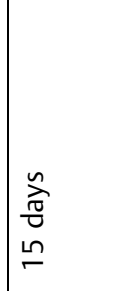 & 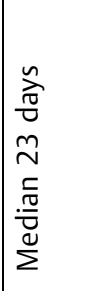 & 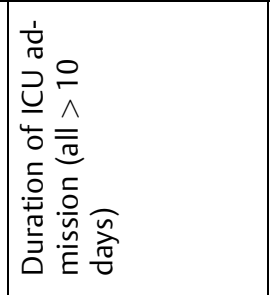 & 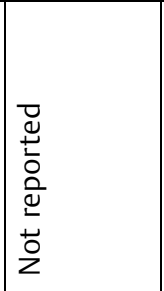 & 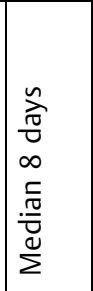 & 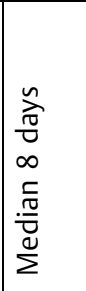 \\
\hline 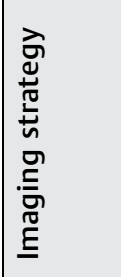 & 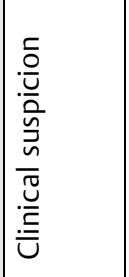 & 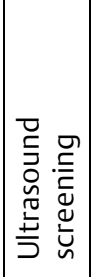 & 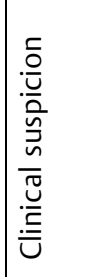 & 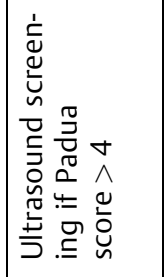 & 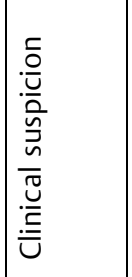 & 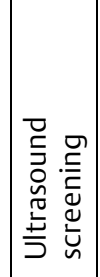 & 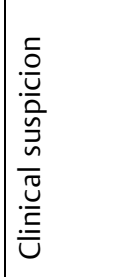 & 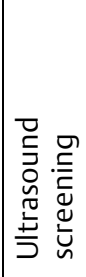 & 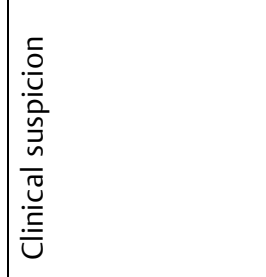 & 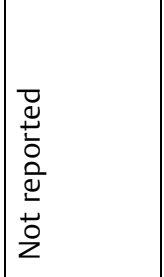 & 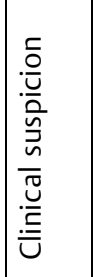 & 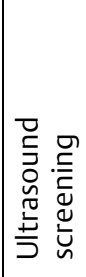 \\
\hline 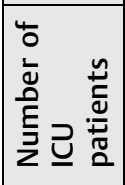 & $\underset{⿱}{\infty}$ & $\stackrel{\llcorner}{\sim}$ & ○ & $\stackrel{\text { ำ }}{\circ}$ & $\stackrel{\text { Ln }}{\wedge}$ & $\stackrel{\nabla}{m}$ & $\stackrel{0}{\circ}$ & $\stackrel{\infty}{\sim}$ & $\stackrel{\infty}{\infty}$ & $\approx$ & $\tilde{\sigma}$ & L \\
\hline 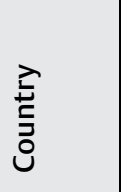 & $\mid \frac{\vec{\pi}}{ \pm}$ & 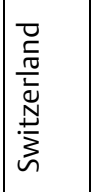 & 芩 & 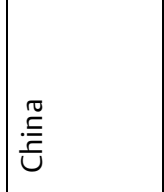 & 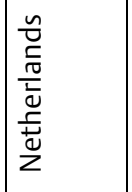 & 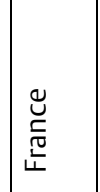 & 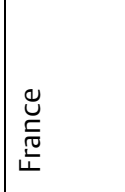 & 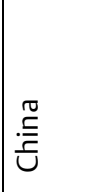 & 兰 & $\begin{array}{l}\frac{\lambda}{\mathbb{E}} \\
\pm\end{array}$ & 兰 & 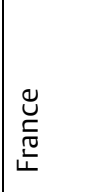 \\
\hline 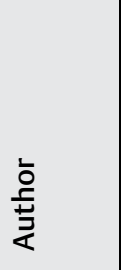 & 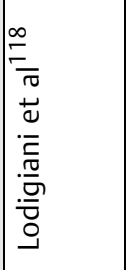 & 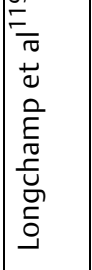 & 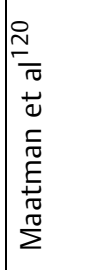 & 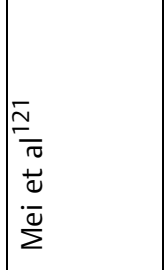 & 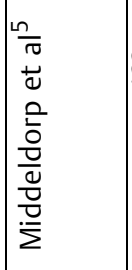 & 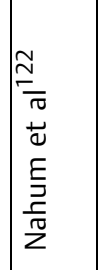 & 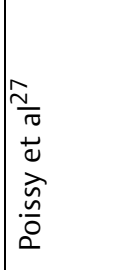 & 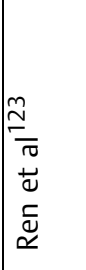 & 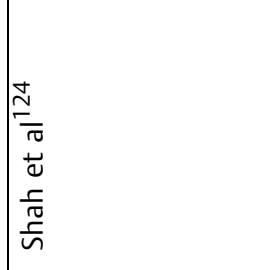 & $\begin{array}{l}\frac{\pi}{\pi} \\
\frac{0}{0} \\
\frac{\pi}{N} \\
\frac{\pi}{a} \\
\frac{\pi}{n}\end{array}$ & 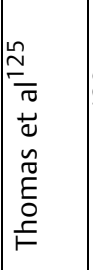 & 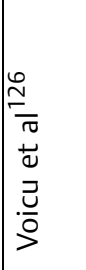 \\
\hline
\end{tabular}


direct comparison of studies describing the incidence of VTE is limited by the various thromboprophylactic regimes used, by differences in patient populations and by the differing imaging modalities used to establish a diagnosis of VTE.

A few studies have compared patients with COVID-19 to historical cohorts of patients with acute respiratory distress syndrome (ARDS) or to critically ill patients with bacterial or viral pneumonia. Helms et al describe an almost sixfold increase in the occurrence of pulmonary embolism (PE) in patients with COVID-19 ARDS compared with non-COVID-19 ARDS (11.7 vs. $2.1 \%, p<0.008){ }^{3}$ Poissy et al report PE rates three times as high in patients with COVID-19 compared with an unselected historic cohort of critically ill patients (20.6\% vs. 6.1\%). Compared with patients with confirmed influenza, the prevalence of PE in patients with COVID-19 was still significantly higher, indicating a difference between CAC and the coagulopathy found in other viral pneumonias. ${ }^{27}$ Of interest, in the same study a low incidence of deep vein thrombosis (DVT) was observed, suggesting primary pulmonary thrombosis rather than embolism of venous thrombi as the primary cause of pulmonary vessel occlusion. ${ }^{27}$ Desborough et al postulate that studies overestimate the number of PEs by labelling segmental and sub-segmental thromboses as emboli. ${ }^{28}$ This concept is supported by imaging studies ${ }^{29}$ which demonstrate that pulmonary thromboses in infected lung parenchyma are smaller and more peripherally located, suggesting that immunothrombosis is more likely to be the causative mechanism of CAC than the typical embolisation of peripheral DVTs to the lungs.

\section{Diagnosis of CAC}

\section{Biochemical Markers}

The diagnosis of COVID-19 is made based on a combination of clinical, laboratory and imaging results (-Table 2 ). Bio- markers not only serve to identify patients with concomitant organ system failures as a marker of poor prognosis, ${ }^{30}$ but also correlate with the severity of COVID-19. ${ }^{9}$ Typical patterns of laboratory results in patients with COVID-19 have been described and are used to direct management strategies in the ED. C-reactive protein, absolute lymphocyte count and other markers of inflammation such as ferritin are independent predictors of disease severity and mortality. 1,31

Increased D-dimer levels are associated with the need for hospitalisation and ICU admission, ${ }^{8,32}$ reflect the severity of disease and predict outcomes. ${ }^{8,33-39}$ Prothrombin time (PT) was found to be modestly prolonged at admission in nonsurvivors and in patients requiring ICU admission, but not in those not requiring ICU admission. ${ }^{8}$ Some studies have reported significantly lower platelet levels in patients with more severe disease and have demonstrated a correlation between thrombocytopenia and mortality. ${ }^{40}$

Given the associations between coagulation test results and patient outcomes, routine measurement of D-dimer, PT and platelet count are widely recommended in all patients with suspected SARS-CoV-2 infection to identify those at higher risk of adverse outcome, including a worsening coagulopathy.

In severe COVID-19, and in particular during the later stages of the disease, normal or mildly reduced platelet counts, ${ }^{40}$ high fibrinogen levels ${ }^{41}$ and mildly elevated PTs have been noted. In contrast, SIC is characterised by severe thrombocytopenia, ${ }^{42,43}$ PT prolongation ${ }^{44}$ and hypofibrinogenaemia. ${ }^{45}$

Several studies have indicated that CAC differs from SIC. Patients with acute respiratory failure due to COVID-19 present with severe hypercoagulability, characterised by fibrin formation and polymerisation rather than a consumptive coagulopathy. ${ }^{3,46}$ Drastically increased thrombin production has been observed, as evidenced by up to 10 -fold increased prothrombin fragments $1+2$ concentrations. ${ }^{47}$

Table 2 Summary of main clinical signs and symptoms, laboratory and imaging findings of patients with COVID-19 upon admission to the emergency department

\begin{tabular}{|c|c|c|c|}
\hline & & Main findings & Other findings \\
\hline \multirow[t]{2}{*}{ Clinical manifestations } & Mild & $\begin{array}{l}\text { Non-specific symptoms (fever, cough, } \\
\text { sputum production, fatigue, } \\
\text { dyspnoea) }\end{array}$ & Diarrhoea, skin rash, conjunctivitis \\
\hline & Severe & $\begin{array}{l}\text { Respiratory failure, ARDS, sepsis, } \\
\text { shock }\end{array}$ & $\begin{array}{l}\text { Myocarditis, acute MI, exacerbation of } \\
\text { heart failure, AKI, neurological } \\
\text { complications }\end{array}$ \\
\hline Laboratory findings & & $\begin{array}{l}\text { Elevated CRP, LDH, fibrinogen, ferritin } \\
\text { and D-dimer levels; eosinopaenia; } \\
\text { lymphocytopaenia; } \\
\text { thrombocytopaenia }\end{array}$ & $\begin{array}{l}\text { Elevated transaminases; anaemia; } \\
\text { modest PT prolongation }\end{array}$ \\
\hline \multirow[t]{3}{*}{ Imaging findings } & CXR & Often inconclusive, bilateral infiltrates & \\
\hline & $\mathrm{CT}$ & $\begin{array}{l}\text { Bilateral and multi-lobar ground glass } \\
\text { opacities; sub-pleural consolidations }\end{array}$ & $\begin{array}{l}\text { Vascular enlargement; inter-lobal sep- } \\
\text { tal thickening; crazy-paving pattern }\end{array}$ \\
\hline & LUS & $\begin{array}{l}\text { Separate and confluent B lines; thick- } \\
\text { ening and irregularity of the pleura; } \\
\text { bilateral consolidation }\end{array}$ & Pleural effusions \\
\hline
\end{tabular}

Abbreviations: AKI, acute kidney injury; ARDS, acute respiratory distress syndrome; CRP, C-reactive protein; CT, computed tomography; CXR, chest Xray; LDH, lactate dehydrogenase; LUS, lung ultrasound; MI, myocardial infarction; PT, prothrombin time. 
Interestingly, in survivors, thrombin generation significantly decreased at follow-up, whereas it remained stable or increased in non-survivors. ${ }^{47}$ Similarly, fibrin generation is massively activated in patients with acute respiratory failure due to COVID-19 infection, with several studies highlighting the markedly elevated fibrinogen levels in critically ill patients. ${ }^{46-48}$

In contrast, SIC is characterised by a consumptive picture, including low platelet counts, decreased plasma levels of clotting factors and prolonged PT. ${ }^{49}$ Excessive activation of plasminogen activator inhibitor-1 reflects vascular endothelial cell dysfunction and leads to fibrinolytic shutdown. ${ }^{49}$ Neither platelet nor clotting factor consumption are commonly observed in $\mathrm{CAC}^{50}$ which emphasises the different pathomechanisms underlying these syndromes. Not surprisingly, compared with patients with SIC, the International Society for Thrombosis and Haemostasis DIC scores are lower in patients with COVID-19.51

\section{Imaging}

Imaging represents a cornerstone of diagnosis in COVID-19 in the ED setting. This is of particular relevance in light of the not negligible rate of false negative real-time reverse transcriptase-polymerase chain reaction tests. ${ }^{52}$ Lung ultrasound (LUS) has rapidly become the first diagnostic approach used at the bedside. ${ }^{7,53-55}$ LUS is not only used in the ED as a screening tool for patients with suspected SARS-CoV-2 infection, but also for monitoring during their hospital admission. Transthoracic echocardiography for patients with elevated cardiac enzymes ${ }^{55}$ or to assess for right heart strain where computed tomography pulmonary angiogram is not feasible and compression ultrasound of the veins of the limbs for patients with a suspected DVT, represent other important applications of bedside ultrasonography in patients with COVID-19. ${ }^{7}$ of note, the prevalence of asymptomatic DVT detected by ultrasound testing upon admission at the ED was found to be low in patients with COVID-19 and routine screening is not considered cost-effective. ${ }^{56}$

\section{Pathological Mechanisms \\ COVID-19 and ARDS}

While COVID-19-related lung disease is mild in the vast majority of patients, progression to ARDS and multi-organ dysfunction is observed in up to $15 \%$ of cases. ${ }^{57}$ Mild, moderate and severe forms of ARDS often involve acute-phase diffuse alveolar damage, which is characterised by exudates and fibrin accumulation in the lung alveoli. ${ }^{58}$ Clinically, pulmonary micro- and macrothrombosis are leading features of COVID19-induced ARDS, affecting mainly small- to medium-sized arteries. ${ }^{16}$ Fibrin deposits and thrombus formation clog intrapulmonary vessels and contribute to ventilation/perfusion mismatch. As a consequence, hypoxic respiratory failure requiring non-invasive or invasive respiratory support is the most common reason for admission to ICU.

Angiotensin-converting enzyme 2 (ACE2), a metallopeptidase, acts as a functional co-receptor for coronavirus entry (-Fig. 1). ACE2 is present in the epithelium of nose, mouth

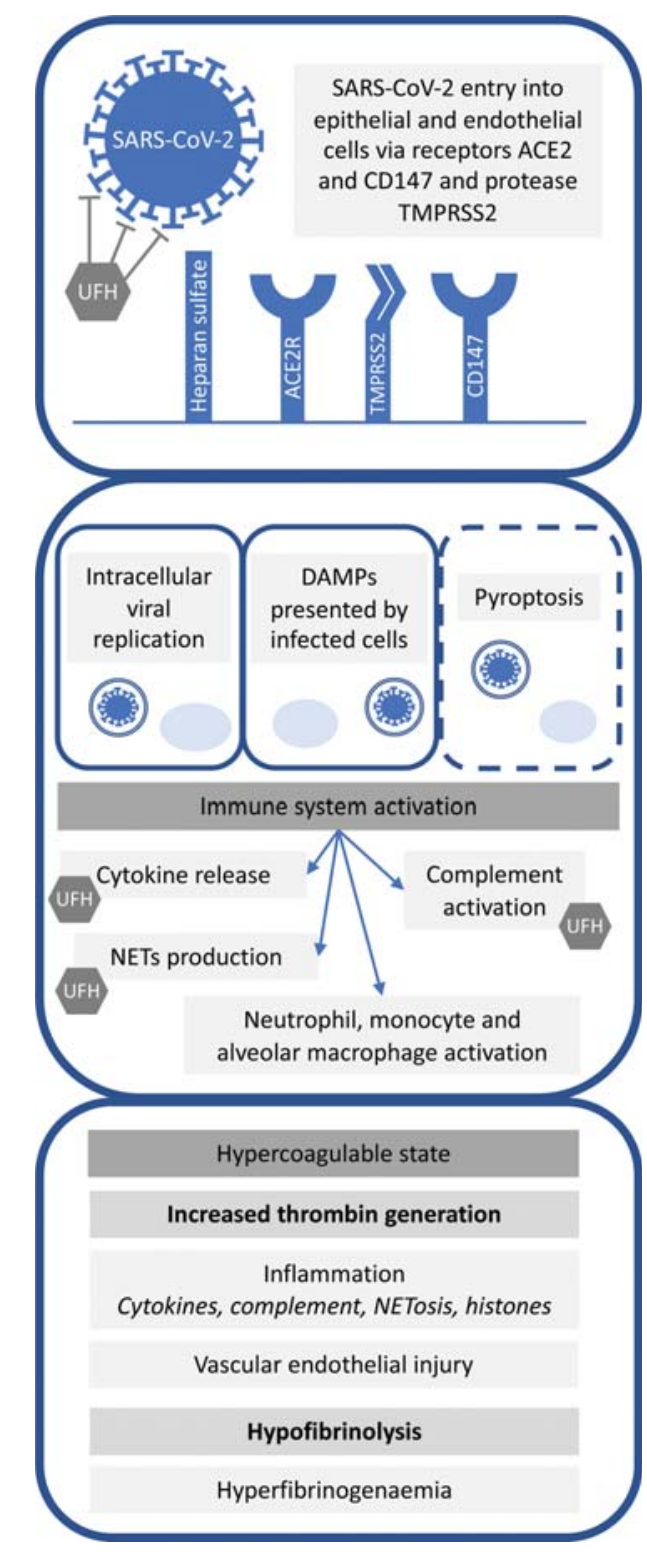

Fig. 1 Overview of pathological mechanisms underlying COVID-19 infection, immune activation and coagulopathy. SARS-CoV-2 has been found within epithelial and endothelial cells, which it enters by binding to CD147 receptors and ACE2 receptors with the assistance of type 2 transmembrane serine protease (TMPRSS2). Heparan sulphate interacts with the SARS-CoV-2 spike glycoprotein adjacent to ACE2R to facilitate binding. Unfractionated heparin binds to the spike protein and blocks this interaction in vitro, whereas low molecular weight heparins (LMWHs) such as enoxaparin and dalteparin are less effective. SARS-CoV-2 replicates within the cell before copies are released. Damage-associated molecular pathogens (DAMPs) are presented by infected cells and pyroptosis triggers an immune response, which results in the recruitment and activation of neutrophils, monocytes and macrophages and the release of cytokines, activation of complement and the production of neutrophil extracellular traps (NETs). Unfractionated heparin counteracts cytokine production, complement activation and NETosis, in addition to reducing other pro-inflammatory molecules. Activation of the immune system also activates the coagulation system, leading to increased thrombin generation. Vascular endothelial injury contributes to thrombin generation and hypercoagulability. High levels of fibrinogen in the presence of raised D-dimer levels indicate a hypofibrinolytic state. ${ }^{59,64,70,111}$ ACE2, angiotensin converting enzyme 2; ACE2R, angiotensin converting enzyme 2 receptor; CD147, cluster of differentiation 147 receptor; DAMPs: damage-associated molecular pathogens; NET, neutrophil extracellular trap; TMPRSS2, transmembrane serine protease 2; UFH, unfractionated heparin. 
and lungs. In the lungs, ACE2 is highly expressed in type I and type II pneumocytes and serves as an entrance site for SARSCoV. ${ }^{59}$ Goshua et al report elevated plasma von Willebrand factor (VWF) concentrations in patients with COVID-19. ${ }^{60}$ VWF is produced in endothelial cells and is either secreted into the plasma or stored within intracellular organelles. Following endothelial cell activation, stored VWF is secreted, binds to platelets, neutrophils and monocytes to initiate microvascular thrombosis. ${ }^{61}$

\section{Immunothrombosis}

Extensive crosstalk exists between the coagulation and immune systems, with both working together to provide effective host defense. ${ }^{62}$ As such, activation of the coagulation system is an integral part of the immune response to infection, ${ }^{63}$ where a dysregulated immune response leads to overactivation of the coagulation system that can progress into DIC and multi-organ failure.

SARS-CoV-2 is thought to trigger dysregulation of thrombo-immune homeostasis, resulting in a prothrombic state, with hypercoagulability and relative hypofibrinolysis. ${ }^{64,65}$ The increased circulating D-dimer concentrations observed in many patients reflect not only pulmonary vascular bed thrombosis, but also activation of fibrinolytic pathways. ${ }^{66}$ However, the high prevalence of PE in the absence of consumptive coagulopathy appears to be due to immunothrombosis as the predominant cause of VTE in patients with severe COVID-19, with endothelial dysfunction being a key event in activation of thrombo-inflammatory cascades. ${ }^{67,68}$

\section{Damage-Associated Molecular Patterns, Neutrophil Extracellular Traps and Histones}

SARS-CoV-2 is thought to trigger pyroptosis of predominantly endothelial cells, ${ }^{69,70}$ causing release of damage-associated molecular patterns such as histones, which in turn activate the thrombo-inflammatory cascade. ${ }^{71}$ Previous studies have shown that extracellular histones, released following cell damage or death, are strong inducers of immunothrombosis. ${ }^{72,73}$ Elevated levels of neutrophil extracellular traps (NETs), web-like structures of deoxyribonucleic acid and proteins expelled from the neutrophil that ensnare pathogens, ${ }^{14}$ have been detected in patients with COVID-19 infection when compared with controls, and a correlation has been identified between the level of NETs and disease severity. ${ }^{74,75}$ Plasma NETosis also correlates directly with the Sequential Organ Failure Assessment score and can predict the development of DIC and mortality ${ }^{76}$ Histones can directly amplify the production of NETs. ${ }^{77}$ Excessive NETosis contributes to organ damage by releasing cytokines, activating the coagulation cascades and contributing to microthrombosis. $^{74,78}$

The presence of histones can affect two anti-coagulant components: activated protein C (APC) and thrombomodulin. Histones inhibit the generation of APC, which can cleave and inactivate histones. ${ }^{79}$ Histones have been shown to bind to both endothelial and soluble thrombomodulin, thereby reducing the production of APC. ${ }^{79}$ The dampening of these anti-coagulation components can therefore remove their inhibition of histones, increase NETosis, lead to an increase in microvascular and macrovascular thrombosis and in turn increase the risk of multi-organ failure. ${ }^{76,80}$

\section{Histological Findings in COVID-19}

Several studies have reported histological analysis of postmortem samples of lung tissue and describe endothelitis $13,15,69,81,82$; thrombotic microangiopathy and thrombo$\operatorname{sis}^{13,15,16,69,81-84}$; infiltration of mononuclear cells ${ }^{13,15,16,69,81-85}$; presence of $\mathrm{NETs}^{13,14}$; infiltration of complement proteins ${ }^{86}$; and angiogenesis ${ }^{81,84}$ as the main pathologies. Endotheliitis, thrombotic microangiopathy and evidence of viral inclusion were also noted within the heart, kidney, liver and skin. ${ }^{15,69,83,86}$ Ackermann et al compared the lungs of patients with COVID-19 to those with influenza and found that alveolar capillary microthrombi were nine times as prevalent in patients who died following severe COVID-19 infection. ${ }^{81}$ However, the reasons for the pathogen-dependent variation in appearance and occurrence of microthrombi remain to be investigated.

Investigations to understand the role of NETosis, endothelial activation and ACE2-mediated effects are underway and may provide routes for development of therapeutic agents. Currently, therapeutic anti-coagulation or intermediate dose thromboprophylaxis with heparins are the only strategies to prevent and treat micro- and macrothrombosis in clinical practice. Differing results have been published from observational studies regarding the clinical outcomes and mortality rates of critically ill patients receiving increased doses of heparins. ${ }^{17,87,88}$ Hence, results from randomised clinical trials are urgently needed.

\section{Prevention of VTE in Patients with COVID-19}

\section{Thromboprophylaxis for Critically III Patients with COVID-19}

Thromboprophylaxis with either low molecular weight heparin (LMWH) or unfractionated heparin (UFH) is routinely recommended for all critically ill patients, ${ }^{89}$ because of their high risk of VTE from a combination of risk factors, including immobilisation, indwelling catheters, mechanical ventilation and inflammation. ${ }^{19,90}$ However, the optimal strategy for thromboprophylaxis in patients with COVID-19 remains controversial. Current discussions focus on the type of heparin used, dosing and frequency of administration. The efficacy of thromboprophylaxis for prevention of VTE in patients with COVID-19 remains uncertain, and further investigation is needed to identify the best monitoring strategies for therapeutic and prophylactic anti-coagulation.

Recommendations for thromboprophylaxis in patients with COVID-19 vary nationally and internationally ${ }^{91}$ (-Table 3). North American guidelines commonly recommend standard dosing of thromboprophylaxis with use of higher doses restricted to clinical trials, whereas European societies suggest using intermediate dose thromboprophylaxis for high-risk and critically ill patients. Common regimens for intermediate thromboprophylaxis include twice 
Table 3 Summary of existing guidelines on thromboprophylaxis for critically ill patients with COVID-19

\begin{tabular}{|c|c|c|c|c|c|}
\hline Group/Author & Country & $\begin{array}{l}\text { Recommended } \\
\text { thromboprophy- } \\
\text { laxis for invasively } \\
\text { ventilated patients } \\
\text { with no clinical } \\
\text { suspicion of VTE }\end{array}$ & $\begin{array}{l}\text { Recommended } \\
\text { thromb } \\
\text { oprophylaxis for } \\
\text { non-invasively ven- } \\
\text { tilated patients }\end{array}$ & $\begin{array}{l}\text { Recommended } \\
\text { thromboprophy- } \\
\text { laxis for patients } \\
\text { on step-down from } \\
\text { ICU to ward }\end{array}$ & $\begin{array}{l}\text { Recommended } \\
\text { length of throm- } \\
\text { boprophylaxis } \\
\text { post-hospital dis- } \\
\text { charge }\end{array}$ \\
\hline $\begin{array}{l}\text { Anti-coagulation } \\
\text { Forum } \\
\text { Barnes et al }\end{array}$ & USA & Intermediate dose & Intermediate dose & $\begin{array}{l}\text { De-escalate to } \\
\text { standard dose }\end{array}$ & $\begin{array}{l}\text { Consider if pro- } \\
\text { longed critical ill- } \\
\text { ness and still } \\
\text { needing extensive } \\
\text { rehabilitation (e.g. } \\
6 \text {-14 days } \\
\text { enoxaparin) }\end{array}$ \\
\hline $\begin{array}{l}\text { American College of } \\
\text { Cardiology } \\
\text { Bikdeli et al }\end{array}$ & USA & Standard dose & Standard dose & Standard dose & $\begin{array}{l}\text { Consider extended } \\
\text { prophylaxis (up to } \\
45 \text { days) for elevat- } \\
\text { ed risk of VTE (crit- } \\
\text { ical illness not } \\
\text { specified) }\end{array}$ \\
\hline 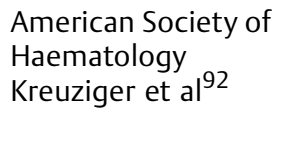 & USA & $\begin{array}{l}\text { Recommend clini- } \\
\text { cal trial } \\
\text { participation }\end{array}$ & Not specified & $\begin{array}{l}\text { At least standard } \\
\text { dose }\end{array}$ & $\begin{array}{l}\text { Can be considered } \\
\text { if high risk or sig- } \\
\text { nificantly reduced } \\
\text { mobility }\end{array}$ \\
\hline $\begin{array}{l}\text { British Thoracic So- } \\
\text { ciety } \\
\text { Condliffe et al }\end{array}$ & UK & $\begin{array}{l}\text { Intermediate dose } \\
\text { for 'high risk' criti- } \\
\text { cally ill patients }\end{array}$ & $\begin{array}{l}\text { Intermediate dose } \\
\text { for 'high risk' criti- } \\
\text { cally ill patients }\end{array}$ & $\begin{array}{l}\text { Standard dose if } \\
\text { 'low risk' }\end{array}$ & $\begin{array}{l}\text { Consider } 4 \text { weeks } \\
\text { thromboprophy- } \\
\text { laxis post-discharge }\end{array}$ \\
\hline $\begin{array}{l}\text { Chinese Consensus } \\
\text { Statement } \\
\text { Zhai et al }{ }^{129}\end{array}$ & China & Standard dose & Standard dose & Not specified & $\begin{array}{l}\text { Consider if 'high } \\
\text { risk' }\end{array}$ \\
\hline $\begin{array}{l}\text { American College of } \\
\text { Chest Physicians } \\
\text { Moores et al }\end{array}$ & USA & Standard dose & Standard dose & Standard dose & Not recommended \\
\hline $\begin{array}{l}\text { French Society of } \\
\text { Thrombosis and } \\
\text { Haemostasis } \\
\text { (GFHT) } \\
\text { Susen et al }\end{array}$ & France & $\begin{array}{l}\text { Intermediate dose. } \\
\text { Higher dosing if BW } \\
\text { over }>120 \mathrm{~kg} \text {. } \\
\text { UFH if } \mathrm{CrCl}<30 \text { - } \\
\mathrm{mL} / \text { min. } \\
\text { Xa monitoring to } \\
\text { avoid overdose. } \\
\text { Therapeutic dose if } \\
\text { fibrinogen }>8 \text { or D- } \\
\text { dimer }>3000 \text { or re- } \\
\text { nal filter } \\
\text { thrombosis }\end{array}$ & Intermediate dose & $\begin{array}{l}\text { Standard dose if } \\
\text { only on oxygen and } \\
\mathrm{BMI}<30\end{array}$ & Not specified \\
\hline $\begin{array}{l}\text { Intensive Care Soci- } \\
\text { ety, Faculty of In- } \\
\text { tensive Care } \\
\text { Medicine, Royal } \\
\text { College of Anaes- } \\
\text { thetists, Royal Col- } \\
\text { lege of Physicians }\end{array}$ & UK & $\begin{array}{l}\text { Intermediate dose } \\
\text { Therapeutic antico- } \\
\text { agulation if fre- } \\
\text { quent renal circuit } \\
\text { clotting or if clinical } \\
\text { suspicion of VTE } \\
\text { without confirma- } \\
\text { tory imaging }\end{array}$ & Intermediate dose & $\begin{array}{l}\text { Consider reducing } \\
\text { to standard dose }\end{array}$ & $\begin{array}{l}\text { Consider } 14-28 \\
\text { days prophylactic } \\
\text { LMWH post- } \\
\text { discharge }\end{array}$ \\
\hline $\begin{array}{l}\text { Italian Society on } \\
\text { Thrombosis \& Hae- } \\
\text { mostasis (SISET) } \\
\text { Marietta et al }\end{array}$ & Italy & $\begin{array}{l}\text { Intermediate dose } \\
\text { for 'high risk' } \\
\text { patients }\end{array}$ & $\begin{array}{l}\text { Intermediate dose } \\
\text { for 'high risk' } \\
\text { patients }\end{array}$ & $\begin{array}{l}\text { Intermediate dose } \\
\text { if } \mathrm{BMI}>30, \mathrm{VTE} \text {, } \\
\text { active cancer }\end{array}$ & $\begin{array}{l}\text { 7-14 days post-dis- } \\
\text { charge if high risk } \\
\text { (e.g. BMI > 30, VTE, } \\
\text { active cancer) }\end{array}$ \\
\hline $\begin{array}{l}\text { International Socie- } \\
\text { ty of Thrombosis } \\
\text { and Haemostasis } \\
\text { (ISTH) }\end{array}$ & International & $\begin{array}{l}\text { Consider interme- } \\
\text { diate dose in 'high } \\
\text { risk' patients }\end{array}$ & Not specified & Not specified & $\begin{array}{l}\text { At least } 14 \text { days } \\
\text { LMWH or DOAC can } \\
\text { be considered in } \\
\text { 'high risk' patients }\end{array}$ \\
\hline
\end{tabular}


Table 3 (Continued)

\begin{tabular}{|c|c|c|c|c|c|}
\hline Group/Author & Country & $\begin{array}{l}\text { Recommended } \\
\text { thromboprophy- } \\
\text { laxis for invasively } \\
\text { ventilated patients } \\
\text { with no clinical } \\
\text { suspicion of VTE }\end{array}$ & $\begin{array}{l}\text { Recommended } \\
\text { thromb } \\
\text { oprophylaxis for } \\
\text { non-invasively ven- } \\
\text { tilated patients }\end{array}$ & $\begin{array}{l}\text { Recommended } \\
\text { thromboprophy- } \\
\text { laxis for patients } \\
\text { on step-down from } \\
\text { ICU to ward }\end{array}$ & $\begin{array}{l}\text { Recommended } \\
\text { length of throm- } \\
\text { boprophylaxis } \\
\text { post-hospital dis- } \\
\text { charge }\end{array}$ \\
\hline \multicolumn{6}{|l|}{$\begin{array}{l}\text { Spyropoulos } \\
\text { et al }\end{array}$} \\
\hline $\begin{array}{l}\text { National Institutes } \\
\text { of Health }(\mathrm{NIH})^{131}\end{array}$ & USA & Standard dose & Standard dose & Standard dose & $\begin{array}{l}\text { Not recommended } \\
\text { routinely but can be } \\
\text { considered if high } \\
\text { risk }\end{array}$ \\
\hline $\begin{array}{l}\text { National Institute of } \\
\text { Public Health of the } \\
\text { Netherlands } \\
\text { Oudkerk et al }{ }^{132}\end{array}$ & Netherlands & Standard dose & Standard dose & Standard dose & Not specified \\
\hline $\begin{array}{l}\text { Swiss Society of } \\
\text { Haematology } \\
\text { Casini et al }\end{array}$ & Switzerland & $\begin{array}{l}\text { Consider interme- } \\
\text { diate or therapeutic } \\
\text { anticoagulation if } \\
\text { signs of severe in- } \\
\text { flammation or re- } \\
\text { spiratory failure }\end{array}$ & Not specified & $\begin{array}{l}\text { At least standard } \\
\text { dosing }\end{array}$ & Not specified \\
\hline
\end{tabular}

Abbreviations: BMI, body mass index; BW, body weight; $\mathrm{CrCl}$, creatinine clearance; DOAC, direct oral anticoagulant; ICU, intensive care unit; LMWH, low molecular weight heparin; UFH, unfractionated heparin; VTE, venous thromboembolism; Xa, anti-Factor Xa.

daily administration of standard doses LMWH, for example, enoxaparin $0.5 \mathrm{mg} / \mathrm{kg}$ bodyweight. Most guidelines recommend against using therapeutic anti-coagulation for primary clot prevention, unless extracorporeal membrane oxygenation is used. It remains unclear as to whether this recommendation should be extended to patients on other forms of extracorporeal support, including haemofiltration or haemodialysis for renal replacement therapy. In clinical practice, recurrent clotting of renal replacement lines is treated with increasing the dose of anti-coagulant therapy. ${ }^{92,93}$

As discussed, several studies have shown high rates of PE, likely caused by immunothrombosis, ${ }^{28}$ and unrelated to typical DVT. Although pharmacological thromboprophylaxis is effective at reducing VTE rates in critically ill patients, the prophylactic value of thromboprophylaxis with LMWH or UFH in CAC with immunothrombosis as the primary pathomechanism remains unclear. Therefore, increasing the heparin dose for thromboprophylaxis may be ineffective, or even harmful due to the increased bleeding risk. ${ }^{94}$ The risk of major haemorrhagic events ${ }^{28}$ needs to be considered before initiating therapeutic anti-coagulation without confirmed or highly suspected VTE outside a clinical trial. In a previous cohort study assessing critically ill patients infected with SARS-CoV-2, 53\% of patients received full therapeutic anticoagulation, and an overall incidence of $20 \%$ for major haemorrhagic events was observed. ${ }^{95}$ Eighty-four per cent of patients with major bleeds were therapeutically anticoagulated, and in $50 \%$ of patients therapeutic anti-coagulation was started empirically. A large cohort study from the United States found no survival benefit from therapeutic anti-coagulation, as the risk of major haemorrhage was $2.8 \%$ compared with a $6.3 \%$ risk of VTE. ${ }^{96}$
While more evidence is needed, the use of 'intermediate' dose anti-coagulation for critically ill patients with COVID19 should be considered. ${ }^{93,97-100}$ A summary of recommendations and an algorithm for anti-coagulatory strategies in critically ill patients with COVID-19 is presented in - Fig. 2. Some guidelines include patients requiring non-invasive respiratory support, such as high flow oxygen, non-invasive ventilation or continuous positive airway pressure within the same risk category as invasively ventilated patients. ${ }^{93,97,101}$

For patients on chronic oral anti-coagulant treatment prior to hospital admission, continuation of the usual drug is not without risks as drug metabolism and enteral absorption are uncertain and the risk of bleeding is increased when admission to critical care is required. The role of direct oral anti-coagulants (DOACs) in the treatment and prophylaxis of CAC remains unclear and is the subject of several on-going randomised controlled trials. In acutely ill patients presenting to ED or ICU, there is currently no role for these agents as oral absorption is commonly disturbed, reversal of anticoagulation in cases of severe bleeding is limited and adverse effects due to drug-drug interactions and lack of controllability of drug effects due to altered metabolism are to be expected. Hence, DOACs are not recommended for thromboprophylaxis in hospitalised patients with COVID. ${ }^{99}$ The same applies to vitamin $\mathrm{K}$ antagonists, which exhibit unreliable and often uncontrollable effects in critically ill patients. Vitamin K antagonists should therefore be discontinued on hospital admission. ${ }^{102}$ When continuation of therapeutic anti-coagulation is required, a switch to UFH or LMWH is advisable. For patients with mechanical heart valves, daily monitoring of the international normalised ratio is required 


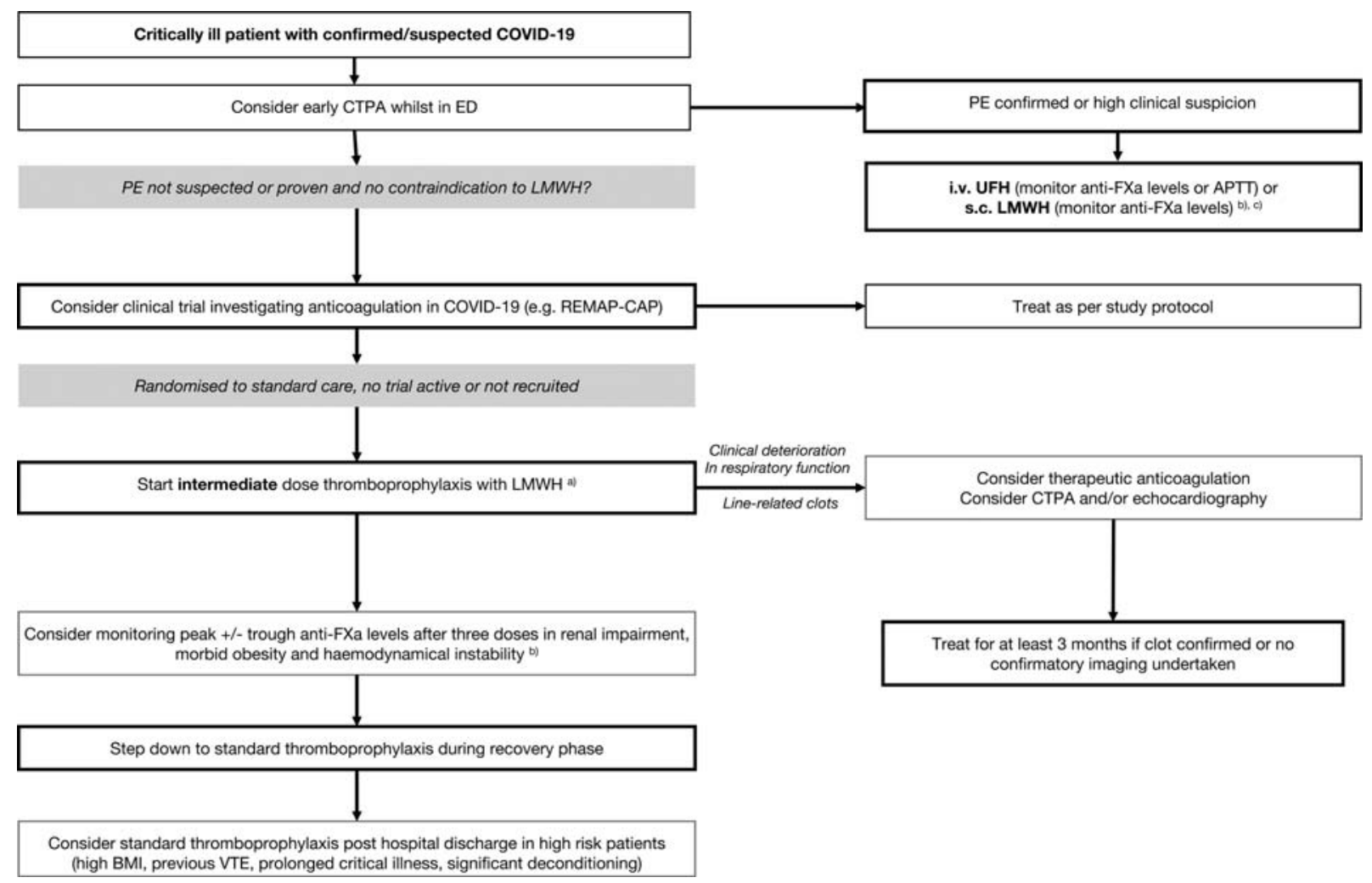

Fig. 2 Proposed scheme for anticoagulation in critically ill patients with COVID-19 based on existing guidelines and evidence. ${ }^{91-93,97,100,101,124,127,133}$ (A) Different dosing regimens exist for intermediate dose thromboprophylaxis, depending on the type of LMWH used: Fixed dose: $40 \mathrm{mg}$ BD enoxaparin or 5000 units BD dalteparin or 4500 units BD tinzaparin, weight-based dose: $0.5 \mathrm{mg} / \mathrm{kg}$ BD enoxaparin, 50 units $/ \mathrm{kg} B D$ tinzaparin, reduced dose in renal impairment (e.g. $\mathrm{CrCl}<30 \mathrm{~mL} / \mathrm{min}$ ): $40 \mathrm{mg}$ OD or $20 \mathrm{mg}$ BD enoxaparin, 5000 units BD or TDS s.c. UFH. For extremes of body weight ( $<50 \mathrm{~kg}$ or $>100 \mathrm{~kg}$ ) dosing based on actual body weight is recommended. (B) Target range of anti-FXa levels: intermediate thromboprophylaxis with LMWH: $0.2-0.4$ units $/ \mathrm{mL}$, therapeutic anticoagulation with LMWH $0.6-1.0 \mathrm{units} / \mathrm{mL}$ and therapeutic anti-coagulation with UFH 0.3-0.7 units/mL. (C) APTT ratio target range depends on reagents used and varies, local guidance should be used. APTT, activated partial thromboplastin time; BD: twice daily; BMI, body mass index; CPAP, continuous positive airway pressure; $\mathrm{CrCl}$, creatinine clearance; CTPA, computed tomography pulmonary angiogram; ED, emergency department; i.v., intravenous; LMWH, low molecular weight heparin; NIV, non-invasive ventilation; OD, once daily; PE, pulmonary embolism; REMAP-CAP, Randomized, Embedded, Multifactorial Adaptive Platform Trial for Community-Acquired Pneumonia; RRT, renal replacement therapy; s.c., subcutaneous; TDS, three times daily; UFH, unfractionated heparin; VTE, venous thromboembolism.

to titrate heparin against the decreasing effect of vitamin $\mathrm{K}$ antagonists to achieve uninterrupted anti-coagulation.

\section{Anti-Factor Xa Monitoring during Thromboprophylaxis}

Anti-factor Xa (anti-FXa) levels are commonly measured to monitor therapeutic anti-coagulation with LMWH. ${ }^{91,93}$ Measurement of anti-FXa activity for thromboprophylaxis is less common, but has been reported in critically ill patients, with anti-FXa levels of 0.2 to 0.4 units/mL considered adequate for thromboprophylaxis. ${ }^{103-105}$ Recently, monitoring of antiFXa activity has been proposed to titrate dosing of LMWH for thromboprophylaxis in patients with COVID-19. ${ }^{106}$ Critically ill patients failed to reach prophylactic anti-FXa levels in over $90 \%$ of cases when standard enoxaparin doses were applied. ${ }^{106}$ Markedly increased acute phase reactants including fibrinogen could contribute to the heparin resistance observed in COVID-19. ${ }^{107}$ Anti-thrombin III deficiency, a recognised cause of heparin resistance, is unlikely to play a role, because anti-thrombin levels are only mildly reduced in severe COVID-19. ${ }^{10}$ There is currently a lack of evidence to indicate which dose of $\mathrm{LMWH}$ is required to achieve the recommended thromboprophylactic levels of anti-FXa. It also remains unclear how efficient thromboprophylactic levels of anti-FXa activity are in preventing CAC and in lowering the risk of thromboembolism.

\section{D-Dimer Levels to Guide Management of Thromboprophylaxis}

Elevated D-dimer levels have been repeatedly demonstrated in patients with COVID-19 108 and are associated with worse outcomes. ${ }^{1}$ Prophylactic doses of LMWH have been suggested to decrease mortality in patients with a SIC score $>4$ or D-dimer levels $>3.0 \mathrm{mg} / \mathrm{L}^{17}$

In view of drastically increased $\mathrm{D}$-dimer concentrations in COVID- $19^{1}$ together with the high incidence of PE and linerelated DVT, the use of increased doses of LMWH or UFH has been suggested for thromboprophylaxis based on D-dimer concentrations. ${ }^{85}$ Recommendations range from standard thromboprophylactic doses to doubling doses to aim for 
therapeutic anti-coagulation depending on D-dimer concentrations. ${ }^{98}$ Potential advantages of using D-dimer over antiFXa levels to guide thromboprophylaxis include more rapidly available results and lower per test costs. However, so far no controlled studies support this approach, and observational studies failed to demonstrate a survival benefit for anti-coagulating patients based on raised D-dimers concentrations. ${ }^{96}$ More research is required before D-dimer-guided anti-coagulation can be recommended.

\section{Treatment of CAC with Anti-Coagulants}

CAC is considered a precipitant factor for severe respiratory failure, ARDS and adverse outcomes. In contrast to other forms of ARDS a surprisingly high respiratory compliance has been observed in some patients, despite severe hypoxaemia and bilateral ground glass opacities on imaging, indicating diffuse and severe lung injury. ${ }^{109}$ Clinically, COVID-19-associated ARDS manifests with profound hypoxia, high respiratory drive and elevated dead space. Microvascular thrombosis and endotheliitis causing occlusion of smaller lung vessels could explain this constellation of clinical symptoms. Hence, administration of anti-coagulants may represent a promising approach to prevent and treat CAC. Prevention and treatment of CAC in acute care represent a continuum, with early thromboprophylaxis upon hospital admission and increased doses of anti-coagulants in severe illness, as well as administration of therapeutic anti-coagulation in established or highly suspected pulmonary thrombosis now being cornerstones of treatment.

The SARS-CoV-2 spike protein has been shown to interact with UFH and LMWH. ${ }^{110}$ UFH inhibited viral infection by $70 \%$ in an in vitro assay and was significantly more potent than equivalent doses of enoxaparin. Together with the observation that anti-coagulant treatment is associated with decreased mortality in COVID-19 patients with coagulopathy, ${ }^{17}$ clinical trials have been designed to assess the efficacy of therapeutic doses of LMWH or UFH in the prevention and treatment of CAC.

The REMAP-CAP trial (https://www.remapcap.org) is an international adaptive platform trial initially developed to investigate community-acquired pneumonia. Its adaptive design has not only allowed addition of novel treatment arms, but also rapid application in a pandemic setting. So far, over 1700 patients with COVID-19 have been recruited. Recently, the COVID-19 therapeutic anti-coagulation domain, which compares local standard venous thromboprophylaxis to therapeutic anti-coagulation with intravenous UFH or subcutaneous LMWH, has opened.

The Antithrombotic Therapy to Ameliorate Complications of COVID-19 (ATTACC) trial, which aims to recruit 3000 participants, is a prospective, open-label, multi-centre, adaptive randomised clinical trial to establish whether therapeutic-dose parenteral anti-coagulation improves outcomes for patients hospitalised with COVID-19 compared with usual care (https://www.clinicaltrials.gov/ct2/show/NCT04372589), defined as thromboprophylactic dose anti-coagulation according to local practice.
As part of the Accelerating COVID-19 Therapeutic Interventions and Vaccines (ACTIV) initiative, the National Institutes of Health has launched an adaptive Phase 3 clinical trials evaluating the safety and effectiveness of LMWH and UFH to treat hospitalised adults diagnosed with COVID-19.

Smaller studies, such as the COVID-HEP(Preventing COVID19 Complications With Low- and High-dose Anticoagulation) study in Switzerland, are assessing the effects of therapeutic doses of UFH or LMWH (enoxaparin) compared with standard thromboprophylaxis on a composite outcome of arterial or venous thrombosis, DIC and all-cause mortality (https:// clinicaltrials.gov/ct2/show/NCT04345848). In Germany, the COVID-PREVENT (Effect of Anticoagulation Therapy on Clinical Outcomes in COVID-19) trial is using rivaroxaban as an intervention to investigate the effects of therapeutic anticoagulation versus standard care (https://clinicaltrials .gov/ct2/show/NCT04416048).

Based on trials in patients with acute lung injury, which found that inhaled UFH reduced pulmonary dead space, coagulation activation, microvascular thrombosis and clinical deterioration, nebulised heparin may represent an attractive alternative to systemic application. ${ }^{111}$ In the United Kingdom, a clinical study on nebulised UFH has been started under the national ACCORD program (ACCORD 2: A Multicentre, Seamless, Phase 2 Adaptive Randomisation Platform Study to Assess the Efficacy and Safety of Multiple Candidate Agents for the Treatment of COVID 19 in Hospitalised Patients). ${ }^{111}$ An international multi-centre randomised controlled trial for nebulised heparin is currently in preparation.

\section{Conclusion}

Despite numerous publications on CAC, the pathophysiology of the disease and why it differs from SIC is not yet fully understood. It has become clear that micro- and macrothrombosis together with inflammation are major drivers of the lung damage observed. In severe SARS-CoV2 , the constellation of hypoxia and consolidation on imaging should trigger a high suspicion of thromboembolic and immunothrombotic events, with a low threshold for computed tomography imaging and consideration of higher doses of anti-coagulation. Extensive research is underway to find more specific therapies for this disease and to build a stronger evidence base for management strategies. Given the hyper-coagulable features of COVID-19 infection, anticoagulatory strategies present promising routes to explore.

Conflict of Interest

None declared.

\section{References}

1 Zhou F, Yu T, Du R, et al. Clinical course and risk factors for mortality of adult inpatients with COVID-19 in Wuhan, China: a retrospective cohort study. Lancet 2020;395(10229):1054-1062

2 Zou Y, Guo H, Zhang Y, et al. Analysis of coagulation parameters in patients with COVID-19 in Shanghai, China. Biosci Trends 2020;14(04):285-289 
3 Helms J, Tacquard C, Severac F, et al;CRICS TRIGGERSEP Group (Clinical Research in Intensive Care and Sepsis Trial Group for Global Evaluation and Research in Sepsis). High risk of thrombosis in patients with severe SARS-CoV-2 infection: a multicenter prospective cohort study. Intensive Care Med 2020;46(06): 1089-1098

4 Klok FA, Kruip MJHA, van der Meer NJM, et al. Incidence of thrombotic complications in critically ill ICU patients with COVID-19. Thromb Res 2020;191:145-147

5 Middeldorp S, Coppens M, van Haaps TF, et al. Incidence of venous thromboembolism in hospitalized patients with COVID19. J Thromb Haemost 2020;18(08):1995-2002

6 Llitjos JF, Leclerc M, Chochois C, et al. High incidence of venous thromboembolic events in anticoagulated severe COVID-19 patients. J Thromb Haemost 2020;18(07):1743-1746

7 Zhang L, Feng X, Zhang D, et al. Deep vein thrombosis in hospitalized patients with COVID-19 in Wuhan, China: prevalence, risk factors, and outcome. Circulation 2020;142(02): 114-128

8 Tang N, Li D, Wang X, Sun Z. Abnormal coagulation parameters are associated with poor prognosis in patients with novel coronavirus pneumonia. J Thromb Haemost 2020;18(04): 844-847

9 Fogarty H, Townsend L, Ni Cheallaigh C, et al. COVID19 coagulopathy in Caucasian patients. Br J Haematol 2020;189(06): 1044-1049

10 Han H, Yang L, Liu R, et al. Prominent changes in blood coagulation of patients with SARS-CoV-2 infection. Clin Chem Lab Med 2020;58(07):1116-1120

11 Iba T, Levy JH, Connors JM, Warkentin TE, Thachil J, Levi M. The unique characteristics of COVID-19 coagulopathy. Crit Care 2020;24(01):360

$12 \mathrm{Li} \mathrm{T}$, Lu H, Zhang W. Clinical observation and management of COVID-19 patients. Emerg Microbes Infect 2020;9(01):687-690

13 Fox SE, Akmatbekov A, Harbert JL, Li G, Quincy Brown J, Vander Heide RS. Pulmonary and cardiac pathology in African American patients with COVID-19: an autopsy series from New Orleans. Lancet Respir Med 2020;8(07):681-686

14 Barnes BJ, Adrover JM, Baxter-Stoltzfus A, et al. Targeting potential drivers of COVID-19: Neutrophil extracellular traps. J Exp Med 2020;217(06):e20200652

15 Wichmann D, Sperhake JP, Lütgehetmann M, et al. Autopsy findings and venous thromboembolism in patients with COVID-19: a prospective cohort study. Ann Intern Med 2020; 173(04):268-277

16 Lax SF, Skok K, Zechner P, et al. Pulmonary arterial thrombosis in COVID-19 with fatal outcome : results from a prospective, singlecenter, clinicopathologic case series. Ann Intern Med 2020;173 (05):350-361

17 Tang N, Bai H, Chen X, Gong J, Li D, Sun Z. Anticoagulant treatment is associated with decreased mortality in severe coronavirus disease 2019 patients with coagulopathy. J Thromb Haemost 2020;18(05):1094-1099

18 Levi M, Schultz M, van der Poll T. Sepsis and thrombosis. Semin Thromb Hemost 2013;39(05):559-566

19 Cook D, Crowther M, Meade M, et al. Deep venous thrombosis in medical-surgical critically ill patients: prevalence, incidence, and risk factors. Crit Care Med 2005;33(07):1565-1571

20 Beitland S, Wimmer H, Lorentsen T, et al. Venous thromboembolism in the critically ill: a prospective observational study of occurrence, risk factors and outcome. Acta Anaesthesiol Scand 2019;63(05):630-638

21 Hirsch DR, Ingenito EP, Goldhaber SZ. Prevalence of deep venous thrombosis among patients in medical intensive care. JAMA 1995;274(04):335-337

22 Harris LM, Curl GR, Booth FV, Hassett JM Jr, Leney G, Ricotta JJ. Screening for asymptomatic deep vein thrombosis in surgical intensive care patients. J Vasc Surg 1997;26(05):764-769
23 Ibrahim EH, Iregui M, Prentice D, Sherman G, Kollef MH, Shannon W. Deep vein thrombosis during prolonged mechanical ventilation despite prophylaxis. Crit Care Med 2002;30(04):771-774

24 Minet C, Potton L, Bonadona A, et al. Venous thromboembolism in the ICU: main characteristics, diagnosis and thromboprophylaxis. Crit Care 2015;19(01):287

25 Zhang C, Zhang Z, Mi J, et al. The cumulative venous thromboembolism incidence and risk factors in intensive care patients receiving the guideline-recommended thromboprophylaxis. Medicine (Baltimore) 2019;98(23):e15833

26 Cui S, Chen S, Li X, Liu S, Wang F. Prevalence of venous thromboembolism in patients with severe novel coronavirus pneumonia. J Thromb Haemost 2020;18(06):1421-1424

27 Poissy J, Goutay J, Caplan M, et al;Lille ICU Haemostasis COVID19 Group. Pulmonary embolism in patients with COVID-19: awareness of an increased prevalence. Circulation 2020;142 (02):184-186

28 Desborough MJR, Doyle AJ, Griffiths A, Retter A, Breen KA, Hunt BJ. Image-proven thromboembolism in patients with severe COVID-19 in a tertiary critical care unit in the United Kingdom. Thromb Res 2020;193:1-4

29 van Dam LF, Kroft LJM, van der Wal LI, et al. Clinical and computed tomography characteristics of COVID-19 associated acute pulmonary embolism: a different phenotype of thrombotic disease? Thromb Res 2020;193:86-89

30 Kwenandar F, Japar KV, Damay V, et al. Coronavirus disease 2019 and cardiovascular system: a narrative review. Int J Cardiol Heart Vasc 2020;29:100557

31 Yuan X, Huang W, Ye B, et al. Changes of hematological and immunological parameters in COVID-19 patients. Int J Hematol 2020;112(04):553-559

32 Huang C, Wang Y, Li X, et al. Clinical features of patients infected with 2019 novel coronavirus in Wuhan, China. Lancet 2020;395 (10223):497-506

33 Guan WJ, Ni ZY, Hu Y, et al;China Medical Treatment Expert Group for Covid-19. Clinical characteristics of coronavirus disease 2019 in China. N Engl J Med 2020;382(18):1708-1720

$34 \mathrm{Li} \mathrm{Y,} \mathrm{Zhao} \mathrm{K,} \mathrm{Wei} \mathrm{H,} \mathrm{et} \mathrm{al.} \mathrm{Dynamic} \mathrm{relationship} \mathrm{between} \mathrm{D-dimer}$ and COVID-19 severity. Br J Haematol 2020;190(01):e24-e27

35 Long H, Nie L, Xiang X, et al. D-dimer and prothrombin time are the significant indicators of severe COVID-19 and poor prognosis. BioMed Res Int 2020;2020:6159720

36 Moreno G, Carbonell R, Bodí M, Rodríguez A. Systematic review of the prognostic utility of D-dimer, disseminated intravascular coagulation, and anticoagulant therapy in COVID-19 critically ill patients [in Spanish]. Med Intensiva 2020. Doi: 10.1016/j. medin.2020.06.006

37 Shah S, Shah K, Patel SB, et al. Elevated D-dimer levels are associated with increased risk of mortality in COVID-19: a systematic review and meta-analysis. Cardiol Rev 2020. Doi: 10.1097/CRD.0000000000000330

38 Yao Y, Cao J, Wang Q et al. D-dimer as a biomarker for disease severity and mortality in COVID-19 patients: a case control study. J Intensive Care 2020;8:49

39 Ye W, Chen G, Li X, et al. Dynamic changes of D-dimer and neutrophil-lymphocyte count ratio as prognostic biomarkers in COVID-19. Respir Res 2020;21(01):169

40 Lippi G, Plebani M, Henry BM. Thrombocytopenia is associated with severe coronavirus disease 2019 (COVID-19) infections: a meta-analysis. Clin Chim Acta 2020;506:145-148

41 Maier CL, Truong AD, Auld SC, Polly DM, Tanksley CL, Duncan A. COVID-19-associated hyperviscosity: a link between inflammation and thrombophilia? Lancet 2020;395(10239):1758-1759

42 Stanworth SJ, Walsh TS, Prescott RJ, Lee RJ, Watson DM, Wyncoll DLIntensive Care Study of Coagulopathy Investigators. Thrombocytopenia and platelet transfusion in UK critical care: a multicenter observational study. Transfusion 2013;53(05): 1050-1058 
43 Baughman RP, Lower EE, Flessa HC, Tollerud DJ. Thrombocytopenia in the intensive care unit. Chest 1993;104(04):1243-1247

44 Chakraverty R, Davidson S, Peggs K, Stross P, Garrard C, Littlewood TJ. The incidence and cause of coagulopathies in an intensive care population. Br J Haematol 1996;93(02):460-463

45 Besser MW, MacDonald SG. Acquired hypofibrinogenemia: current perspectives. J Blood Med 2016;7:217-225

46 Spiezia L, Boscolo A, Poletto F, et al. COVID-19-related severe hypercoagulability in patients admitted to intensive care unit for acute respiratory failure. Thromb Haemost 2020;120(06): 998-1000

47 Ranucci M, Sitzia C, Baryshnikova E, et al. Covid-19-associated coagulopathy: biomarkers of thrombin generation and fibrinolysis leading the outcome. J Clin Med 2020;9(11):E3487

48 Panigada M, Bottino N, Tagliabue P, et al. Hypercoagulability of COVID-19 patients in intensive care unit: a report of thromboelastography findings and other parameters of hemostasis. J Thromb Haemost 2020;18(07):1738-1742

49 Iba T, Levy JH, Raj A, Warkentin TE. Advance in the management of sepsis-induced coagulopathy and disseminated intravascular coagulation. J Clin Med 2019;8(05):E728

50 Umemura Y, Yamakawa K, Kiguchi T, Nishida T, Kawada M, Fujimi S. Hematological phenotype of COVID-19-induced coagulopathy: far from typical sepsis-induced coagulopathy. J Clin Med 2020;9(09):E2875

51 Hoechter DJ, Becker-Pennrich A, Langrehr J, et al. Higher procoagulatory potential but lower DIC score in COVID-19 ARDS patients compared to non-COVID-19 ARDS patients. Thromb Res 2020;196:186-192

52 Abbasi-Oshaghi E, Mirzaei F, Farahani F, Khodadadi I, Tayebinia H. Diagnosis and treatment of coronavirus disease 2019 (COVID19): laboratory, PCR, and chest CT imaging findings. Int J Surg 2020;79:143-153

53 Convissar DL, Gibson LE, Berra L, Bittner EA, Chang MG. Application of lung ultrasound during the COVID-19 pandemic: a narrative review. Anesth Analg 2020;131(02):345-350

54 Smith MJ, Hayward SA, Innes SM, Miller ASC. Point-of-care lung ultrasound in patients with COVID-19 - a narrative review. Anaesthesia 2020;75(08):1096-1104

55 Szekely Y, Lichter Y, Taieb P, et al. Spectrum of cardiac manifestations in COVID-19: a systematic echocardiographic study. Circulation 2020;142(04):342-353

56 Pizzi R, Gini G, Caiano L, et al. Coagulation parameters and venous thromboembolism in patients with and without COVID-19 admitted to the emergency department for acute respiratory insufficiency. Thromb Res 2020;196:209-212

57 Sun P, Qie S, Liu Z, Ren J, Li K, Xi J. Clinical characteristics of hospitalized patients with SARS-CoV-2 infection: a single arm meta-analysis. J Med Virol 2020;92(06):612-617

$58 \mathrm{Xu} \mathrm{Z}$, Shi L, Wang Y, et al. Pathological findings of COVID-19 associated with acute respiratory distress syndrome. Lancet Respir Med 2020;8(04):420-422

59 Clausen TM, Sandoval DR, Spliid CB, et al. SARS-CoV-2 infection depends on cellular heparan sulfate and ACE2. Cell 2020. Doi: 10.1016/j.cell.2020.09.033

60 Goshua G, Pine AB, Meizlish ML, et al. Endotheliopathy in COVID19-associated coagulopathy: evidence from a single-centre, cross-sectional study. Lancet Haematol 2020:S2352-3026(20) 30216-7

61 O'Sullivan JM, Gonagle DM, Ward SE, Preston RJS, O'Donnell JS. Endothelial cells orchestrate COVID-19 coagulopathy. Lancet Haematol 2020;7(08):e553-e555

62 Antoniak S. The coagulation system in host defense. Res Pract Thromb Haemost 2018;2(03):549-557

63 Engelmann B, Massberg S. Thrombosis as an intravascular effector of innate immunity. Nat Rev Immunol 2013;13(01):34-45

64 Frantzeskaki F, Armaganidis A, Orfanos SE. Immunothrombosis in acute respiratory distress syndrome: cross talks between inflammation and coagulation. Respiration 2017;93(03): 212-225

65 Hunt B, Retter A, McClintock C. Practical guidance for the prevention of thrombosis and management of coagulopathy and disseminated intravascular coagulation of patients infected with COVID-19. Accessed May 8, 2020 at: https:// thrombosisuk.org/downloads/T\&H\%20and\%20COVID.pdf

66 McGonagle D, O’Donnell JS, Sharif K, Emery P, Bridgewood C. Immune mechanisms of pulmonary intravascular coagulopathy in COVID-19 pneumonia. Lancet Rheumatol 2020;2(07): e437-e445

67 Price LC, McCabe C, Garfield B, Wort SJ. Thrombosis and COVID19 pneumonia: the clot thickens!. Eur Respir J 2020;56(01): 2001608

68 Pons S, Fodil S, Azoulay E, Zafrani L. The vascular endothelium: the cornerstone of organ dysfunction in severe SARS-CoV-2 infection. Crit Care 2020;24(01):353

69 Varga Z, Flammer AJ, Steiger P, et al. Endothelial cell infection and endotheliitis in COVID-19. Lancet 2020;395(10234):1417-1418

70 Tay MZ, Poh CM, Rénia L, MacAry PA, Ng LFP. The trinity of COVID-19: immunity, inflammation and intervention. Nat Rev Immunol 2020;20(06):363-374

71 Silk E, Zhao H, Weng H, Ma D. The role of extracellular histone in organ injury. Cell Death Dis 2017;8(05):e2812

72 Abrams ST, Zhang N, Manson J, et al. Circulating histones are mediators of trauma-associated lung injury. Am J Respir Crit Care Med 2013;187(02):160-169

73 Qaddoori Y, Abrams ST, Mould P, et al. Extracellular histones inhibit complement activation through interacting with complement component 4. J Immunol 2018;200(12):4125-4133

74 Zuo Y, Yalavarthi S, Shi H, et al. Neutrophil extracellular traps in COVID-19. JCI Insight 2020;5(11):138999

75 Middleton EA, He XY, Denorme F, et al. Neutrophil extracellular traps contribute to immunothrombosis in COVID-19 acute respiratory distress syndrome. Blood 2020;136(10):1169-1179

76 Abrams ST, Morton B, Alhamdi Y, et al. A novel assay for neutrophil extracellular trap formation independently predicts disseminated intravascular coagulation and mortality in critically ill patients. Am J Respir Crit Care Med 2019;200(07): 869-880

77 Alhamdi Y, Toh CH. Recent advances in pathophysiology of disseminated intravascular coagulation: the role of circulating histones and neutrophil extracellular traps. F1000 Res 2017; 6:2143

78 Porto BN, Stein RT. Neutrophil extracellular traps in pulmonary diseases: too much of a good thing? Front Immunol 2016;7:311

79 Ammollo CT, Semeraro F, Xu J, Esmon NL, Esmon CT. Extracellular histones increase plasma thrombin generation by impairing thrombomodulin-dependent protein $\mathrm{C}$ activation. J Thromb Haemost 2011;9(09):1795-1803

80 Cheng Z, Abrams ST, Alhamdi Y, et al. Circulating histones are major mediators of multiple organ dysfunction syndrome in acute critical illnesses. Crit Care Med 2019;47(08):e677-e684

81 Ackermann M, Verleden SE, Kuehnel M, et al. Pulmonary vascular endothelialitis, thrombosis, and angiogenesis in Covid-19. N Engl J Med 2020;383(02):120-128

82 Buja LM, Wolf DA, Zhao B, et al. The emerging spectrum of cardiopulmonary pathology of the coronavirus disease 2019 (COVID-19): report of 3 autopsies from Houston, Texas, and review of autopsy findings from other United States cities. Cardiovasc Pathol 2020;48:107233

83 Yao XH, Li TY, He ZC, et al. A pathological report of three COVID19 cases by minimal invasive autopsies [in Chinese]. Zhonghua Bing Li Xue Za Zhi 2020;49(05):411-417

84 Carsana L, Sonzogni A, Nasr A, et al. Pulmonary post-mortem findings in a series of COVID-19 cases from northern Italy: a twocentre descriptive study. Lancet Infect Dis 2020;20(10): 1135-1140 
85 Schaller T, Hirschbühl K, Burkhardt K, et al. Postmortem examination of patients with COVID-19. JAMA 2020;323(24): 2518-2520

86 Magro C, Mulvey JJ, Berlin D, et al. Complement associated microvascular injury and thrombosis in the pathogenesis of severe COVID-19 infection: a report of five cases. Transl Res 2020;220:1-13

87 Musoke N, Lo KB, Albano J, et al. Anticoagulation and bleeding risk in patients with COVID-19. Thromb Res 2020;196:227-230

88 Patell R, Bogue T, Koshy A, et al. Postdischarge thrombosis and hemorrhage in patients with COVID-19. Blood 2020;136(11): 1342-1346

89 National Institute for Health and Care Excellence. Venous thromboembolism in over 16s: reducing the risk of hospital-acquired deep vein thrombosis or pulmonary embolism. (NICE Guideline 89) Accessed May 8, 2020 at: https://www.nice.org.uk/guidance/ng89

90 Najem MY, Couturaud F, Lemarié CA. Cytokine and chemokine regulation of venous thromboembolism. J Thromb Haemost 2020;18(05):1009-1019

91 Flaczyk A, Rosovsky RP, Reed CT, Bankhead-Kendall BK, Bittner EA, Chang MG. Comparison of published guidelines for management of coagulopathy and thrombosis in critically ill patients with COVID 19: implications for clinical practice and future investigations. Crit Care 2020;24(01):559

92 Kreuziger LB, Lee AI, Garcia D, et al. COVID-19 and VTE/Anticoagulation: Frequently Asked Questions, Version 4.0. Accessed August 1, 2020 at: https://www.hematology.org/covid19/covid-19-and-vte-anticoagulation

93 Intensive Care Society, Faculty of Intensive Care Medicine, Royal College of Anaesthetists, Royal College of Physicians. Clinical guide for the prevention, detection and management of thromboembolic disease in patients with COVID-19. Accessed June 30, 2020 at: https://icmanaesthesiacovid-19.org/clinical-guideprevention-detection-and-management-of-vte-in-patientswith-covid-19

94 Cattaneo M, Bertinato EM, Birocchi S, et al. Pulmonary embolism or pulmonary thrombosis in COVID-19? Is the recommendation to use high-dose heparin for thromboprophylaxis justified? Thromb Haemost 2020;120(08):1230-1232

95 Fraissé M, Logre E, Pajot O, Mentec H, Plantefève G, Contou D. Thrombotic and hemorrhagic events in critically ill COVID-19 patients: a French monocenter retrospective study. Crit Care 2020;24(01):275

96 Al-Samkari H, Gupta S, Karp RLeaf, Wang W, Rosovsky R, Bauer K, Leaf DSTOP-COVID Investigators. Thrombosis, bleeding, and the effect of anticoagulation on survival in critically ill patients with COVID-19 in the United States [abstract]. Res Pract Thromb Haemost 2020;(04, Suppl 1. Accessed November 27, 2020 at:https://abstracts. isth.org/abstract/thrombosis-bleeding-and-the-effect-of-anticoagulation-on-survival-in-critically-ill-patients-with-covid-19-in-theunited-states/. Accessed November 27, 2020

97 Susen S, Tacquard CA, Godon A, et al;GIHP and GFHT. Prevention of thrombotic risk in hospitalized patients with COVID-19 and hemostasis monitoring. Crit Care 2020;24(01):364

98 Atallah B, Mallah SI, AlMahmeed W. Anticoagulation in COVID19. Eur Heart J Cardiovasc Pharmacother 2020;6(04):260-261

99 Moores LK, Tritschler T, Brosnahan S, et al. Prevention, diagnosis, and treatment of VTE in patients with coronavirus disease 2019: CHEST guideline and expert panel report. Chest 2020;158(03): 1143-1163

100 Spyropoulos AC, Levy JH, Ageno W, et al;Subcommittee on Perioperative, Critical Care Thrombosis, Haemostasis of the Scientific, Standardization Committee of the International Society on Thrombosis and Haemostasis. Scientific and Standardization Committee communication: clinical guidance on the diagnosis, prevention, and treatment of venous thromboembo- lism in hospitalized patients with COVID-19. J Thromb Haemost 2020;18(08):1859-1865

101 Condliffe R, Bunclark K, Hurdman J, et al. BTS Guidance on Venous Thromboembolic Disease in patients with COVID-19. Accessed May 8, 2020 at: https://www.brit-thoracic.org.uk/document-library/quality-improvement/covid-19/bts-guidance-on-venousthromboembolic-disease-in-patients-with-covid-19/

102 Testa S, Paoletti O, Giorgi-Pierfranceschi M, Pan A. Switch from oral anticoagulants to parenteral heparin in SARS-CoV-2 hospitalized patients. Intern Emerg Med 2020;15(05):751-753

103 Duplaga BA, Rivers CW, Nutescu E. Dosing and monitoring of low-molecular-weight heparins in special populations. Pharmacotherapy 2001;21(02):218-234

104 Kufel WD, Seabury RW, Darko W, Probst LA, Miller CD. Clinical feasibility of monitoring enoxaparin anti-Xa concentrations: are we getting it right? Hosp Pharm 2017;52(03):214-220

105 Wei MY, Ward SM. The anti-factor Xa range for low molecular weight heparin thromboprophylaxis. Hematol Rep 2015;7(04): 5844

106 Dutt T, Simcox D, Downey C, et al. Thromboprophylaxis in COVID-19: anti-FXa-the missing factor? Am J Respir Crit Care Med 2020;202(03):455-457

107 Connors JM, Levy JH. COVID-19 and its implications for thrombosis and anticoagulation. Blood 2020;135(23):2033-2040

108 Lippi G, Favaloro EJ. D-dimer is associated with severity of coronavirus disease 2019: a pooled analysis. Thromb Haemost 2020;120(05):876-878

109 Li X, Ma X. Acute respiratory failure in COVID-19: is it "typical" ARDS? Crit Care 2020;24(01):198

110 Mycroft-West C, Su D, Elli S, et al. The 2019 coronavirus (SARSCoV-2) surface protein (Spike) S1 receptor binding domain undergoes conformational change upon heparin binding. bioRxiv 2020: 2020.02.29.971093

111 van Haren FMP, Page C, Laffey JG, et al. Nebulised heparin as a treatment for COVID-19: scientific rationale and a call for randomised evidence. Crit Care 2020;24(01):454

112 Al-Samkari H, Karp Leaf RS, Dzik WH, et al. COVID-19 and coagulation: bleeding and thrombotic manifestations of SARSCoV-2 infection. Blood 2020;136(04):489-500

113 Bompard F, Monnier H, Saab I, et al. Pulmonary embolism in patients with COVID-19 pneumonia. Eur Respir J 2020;56(01): 2001365

114 Grillet F, Behr J, Calame P, Aubry S, Delabrousse E. Acute pulmonary embolism associated with COVID-19 pneumonia detected with pulmonary CT angiography. Radiology 2020;296(03): E186-E188

115 Hékimian G, Lebreton G, Bréchot N, Luyt C-E, Schmidt M, Combes A. Severe pulmonary embolism in COVID-19 patients: a call for increased awareness. Crit Care 2020;24(01):274

116 Hippensteel JA, Burnham EL, Jolley SE. Prevalence of venous thromboembolism in critically ill patients with COVID-19. Br J Haematol 2020;190(03):e134-e137

117 Léonard-Lorant I, Delabranche X, Séverac F, et al. Acute pulmonary embolism in patients with COVID-19 at CT angiography and relationship to D-dimer levels. Radiology 2020;296(03):E189-E191

118 Lodigiani C, Iapichino G, Carenzo L, et al;Humanitas COVID-19 Task Force. Venous and arterial thromboembolic complications in COVID-19 patients admitted to an academic hospital in Milan, Italy. Thromb Res 2020;191:9-14

119 Longchamp A, Longchamp J, Manzocchi-Besson S, et al. Venous thromboembolism in critically Ill patients with COVID-19: results of a screening study for deep vein thrombosis. Res Pract Thromb Haemost 2020;4(05):842-847

120 Maatman TK, Jalali F, Feizpour C, et al. Routine venous thromboembolism prophylaxis may be inadequate in the hypercoagulable state of severe coronavirus disease 2019. Crit Care Med 2020; 48(09):e783-e790 
121 Mei F, Fan J, Yuan J, et al. Comparison of venous thromboembolism risks between COVID-19 pneumonia and community-acquired pneumonia patients. Arterioscler Thromb Vasc Biol 2020; 40(09):2332-2337

122 Nahum J, Morichau-Beauchant T, Daviaud F, et al. Venous thrombosis among critically ill patients with coronavirus disease 2019 (COVID-19). JAMA Netw Open 2020;3(05):e2010478

123 Ren B, Yan F, Deng Z, et al. Extremely high incidence of lower extremity deep venous thrombosis in 48 patients with severe COVID-19 in Wuhan. Circulation 2020;142(02):181-183

124 Shah A, Donovan K, McHugh A, et al. Thrombotic and haemorrhagic complications in critically ill patients with COVID-19: a multicentre observational study. Crit Care 2020;24(01):561

125 Thomas W, Varley J, Johnston A, et al. Thrombotic complications of patients admitted to intensive care with COVID-19 at a teaching hospital in the United Kingdom. Thromb Res 2020;191:76-77

126 Voicu S, Bonnin P, Stépanian A, et al. High prevalence of deep vein thrombosis in mechanically ventilated COVID-19 patients. J Am Coll Cardiol 2020;76(04):480-482

127 Barnes GD, Burnett A, Allen A, et al. Thromboembolism and anticoagulant therapy during the COVID-19 pandemic: interim clinical guidance from the anticoagulation forum. J Thromb Thrombolysis 2020;50(01):72-81

128 Bikdeli B, Madhavan MV, Jimenez D, et al;Global COVID-19 Thrombosis Collaborative Group, Endorsed by the ISTH, NATF,
ESVM, and the IUA, Supported by the ESC Working Group on Pulmonary Circulation and Right Ventricular Function. COVID19 and thrombotic or thromboembolic disease: implications for prevention, antithrombotic therapy, and follow-up: JACC stateof-the-art review. J Am Coll Cardiol 2020;75(23):2950-2973

129 Zhai Z, Li C, Chen Y, et al; Prevention Treatment of VTE Associated with COVID-19 Infection Consensus Statement Group. Prevention and treatment of venous thromboembolism associated with coronavirus disease 2019 infection: a consensus statement before guidelines. Thromb Haemost 2020;120(06):937-948

130 Marietta M, Ageno W, Artoni A, et al. COVID-19 and haemostasis: a position paper from Italian Society on Thrombosis and Haemostasis (SISET). Blood Transfus 2020;18(03):167-169

131 National Institute of Health. Antithrombotic Therapy in Patients with COVID-19. Accessed August 1, 2020 at: https://www.covid19treatmentguidelines.nih.gov/adjunctive-therapy/antithrombotic-therapy/

132 Oudkerk M, Büller HR, Kuijpers D, et al. Diagnosis, prevention, and treatment of thromboembolic complications in COVID-19: report of the National Institute for Public Health of the Netherlands. Radiology 2020;297(01):E216-E222

133 Casini A, Alberio L, Angelillo-Scherrer A, et al. Thromboprophylaxis and laboratory monitoring for in-hospital patients with COVID-19 - a Swiss consensus statement by the Working Party Hemostasis. Swiss Med Wkly 2020;150:w20247 